\begin{tabular}{|c|c|c|}
\hline \multirow[t]{2}{*}{ 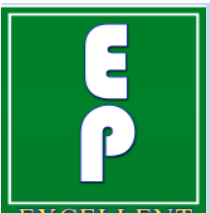 } & $\begin{array}{l}\text { International Journal of Current Research in } \\
\text { Biosciences and Plant Biology }\end{array}$ & \\
\hline & Volume $4 \bullet$ Number 8 (August-2017) • ISSN: 2349-8080 (Online) & \\
\hline $\begin{array}{l}\text { EXCELLENT } \\
\text { PUBLISHERS }\end{array}$ & Journal homepage: www.ijcrbp.com & www.jicrbo com \\
\hline
\end{tabular}

\title{
Stability of Vitamin C in Selected Vegetables under Different Storage Conditions
}

\author{
Bandaru. V.S.R.K.P. Ganesh Sandeep, Pradeep Kumar Jha, K. Raju and M. K. Sukumaran* \\ Department of Biochemistry, Bhavan's Vivekananda College, Secunderabad-500 094, Telangana, India
}

*Corresponding author.

\begin{abstract}
Vegetables and fruits are natural source of biological antioxidants. Vitamin $\mathrm{C}$ is an essential micronutrient which plays an important role in human health. Its deficiency results in a disease referred to as scurvy in humans. The objective of this study was to determine the amount of vitamin $\mathrm{C}$ in some selected vegetables procured from local market in Hyderabad city. In addition, the effect of storage conditions (refrigerated temperature $\left(4^{\circ} \mathrm{C}\right)$ and room temperature) on percentage reduction of vitamin $\mathrm{C}$ in these vegetables was also analyzed on day 2, 4 and 6 of storage period. Results revealed that there was a reduction of vitamin $\mathrm{C}$ content in vegetables stored both at refrigerated temperature $\left(4^{\circ} \mathrm{C}\right)$ and room temperature. However, the reduction was higher in vegetables stored at room temperature as compared to those stored at refrigerated temperature $\left(4^{\circ} \mathrm{C}\right)$.
\end{abstract}

\section{Article Info}

Accepted: 31 July 2017

Available Online: 06 August 2017

\section{Keywords}

Storage temperature

Titrimetric analysis

Vegetables

Vitamin C

\section{Introduction}

Vegetables and fruits are natural source of vitamin C (ascorbic acid). Humans, other primates, guinea pig, bats, Passeriformes birds, and most fishes and invertebrate fail to synthesize this vitamin endogenously (El-Ishaq and Obirinakem, 2015). Therefore, these species acquire vitamin $\mathrm{C}$ through their diet (Goodman et al., 1998; Li and Schellhorn, 2007). Consumption of a healthy diet fulfils the daily requirement of vitamin $\mathrm{C}$, however, higher quantities are required in individuals after surgery, injury, burns and exposure to extremes of temperature. Smokers, women taking contraceptives and people living with high levels of carbon monoxide are at the risk of developing vitamin $\mathrm{C}$ deficiency (Njoku, 2011). Some of the important functions mediated by vitamin $\mathrm{C}$ in humans are, growth and maintenance of healthy bones, teeth, gums, ligaments and blood vessels, proper functioning of the body (by virtue of its antioxidant activity) (Benzie, 1999; Davey et al., 2000) and neutralization of free radicals, which on accumulation can be harmful to the body (Cioroi, 2007). Deficiency of vitamin C in human leads to scurvy, (symptoms are, hemorrhaging in gums and skin, loosening of the teeth, joint pains and exhaustion (Brody, 1994). Among the different factor which causes loss of vitamin $\mathrm{C}$ in fresh produce include, duration of storage, storage temperatures, relative humidity, physical damage and chilling injury (Lee and Kader, 2000).

Many chemical reactions contribute to the loss of storage life of vitamin $\mathrm{C}$ which ultimately leads to chemical deterioration of fruits. It is highly sensitive to oxidation and can be easily destroyed on heating and storage at higher temperatures. Keeping in view the 
importance of vitamin $\mathrm{C}$ in human health and disease the following project was conducted to determine the levels of vitamin $\mathrm{C}$ in selected vegetables that were stored at refrigerated temperature $\left(4^{\circ} \mathrm{C}\right)$ and room temperature.

\section{Materials and methods}

\section{Vegetables}

Vegetables used in this study were purchased from the local market in Hyderabad city. Before the extraction procedure, all the samples were thoroughly cleansed using deionised water to remove any adhering contaminants if present.

\section{Determination of vitamin C}

Vitamin C content in fresh and stored vegetables was determined by the procedure outlined by Deekshika et al. (2015) and Rao and Deshpande (2006).

\section{Method}

Extraction of the sample: $5 \mathrm{~g}$ of the edible portion of the vegetable was accurately weighed and ground in a mortar and pestle with the addition of $10 \mathrm{~mL}$ of $4 \%$ (w/v) oxalic acid. After straining through four layers of muslin cloth the extract was further ground with the addition of $5 \mathrm{~mL}$ of $4 \%$ (w/v) oxalic acid and strained through muslin cloth as described earlier. The final volume of the extract was made up to $25 \mathrm{~mL}$ with $4 \%$ oxalic acid in a standard flask. Analysis of the sample was based on the 2, 6-dichlorophenol indophenol (DCPIP) titration method. All the vegetables were similarly treated.

Estimation of ascorbic acid: $5 \mathrm{~mL}$ of the ascorbic acid working standard (conc. $=100 \mu \mathrm{g} / \mathrm{mL}$ or $500 \mu \mathrm{g} / 5 \mathrm{~mL}$ ) was pipetted out into a $100 \mathrm{~mL}$ conical flask. To this 10 $\mathrm{mL}$ of $4 \%$ oxalic acid was added. After mixing thoroughly, the contents in the conical flask was titrated against the dye solution taken in a burette. End point was indicated by the appearance of pink colour which persists for a few min. All the sample extracts were similarly treated.

\section{Calculations}

Ascorbic acid $(\mathrm{mg} / 100 \mathrm{~g})=\frac{500 \mu \mathrm{g}}{\text { Titre of standard }} \times$ Titre of unknown $\times 01$

\section{Results and discussion}

Vegetables are rich source of minerals, vitamins, dietary fiber, carbohydrates, proteins and energy (Jany et al., 2008). Therefore, vegetables if consumed regularly can be a natural source of the above compounds that are required for the proper function of the body. Vitamin $\mathrm{C}$ is an essential micronutrient that plays a vital role in human health (El-Ishaq and Obirinakem, 2015).

Coriander, small chilli, bitter guard, cabbage, giant chilli and lemon were stored at refrigerated temperature $\left(4^{\circ} \mathrm{C}\right)$ and room temperature for a period of 6 days. Vitamin $\mathrm{C}$ content in these vegetables was analyzed on day 2,4 and 6 of storage period. Vitamin C content in the fresh vegetables was determined on the day of purchase and it was considered as $100 \%$ and percentage loss of vitamin $\mathrm{C}$ was calculated on day 2, 4 and 6 after storage.

\section{Determination of vitamin $\mathrm{C}$ content in fresh vegetables}

The vitamin $\mathrm{C}$ content among the different vegetables varied significantly (Table 1). In their fresh state, vitamin $\mathrm{C}$ content was found to be highest in coriander $(125.78 \pm 1.20 \mathrm{mg} / 100 \mathrm{~g})$ and lowest in lemon $(25.5 \pm$ $1.76 \mathrm{mg} / 100 \mathrm{~g}$ ) (Table 1 and Fig. 1) among the different vegetables. The vitamin $\mathrm{C}$ content $(\mathrm{mg} / 100 \mathrm{~g})$ in different vegetables are coriander $(125.78 \pm 1.20)$, small chilli $(96.19 \pm 0.61)$, bitter guard (56.64 \pm 0.58$)$, cabbage $(45.02 \pm 0.58)$, giant chilli $(36.23 \pm 0.46)$ and lemon $(25.5 \pm 1.76)$ respectively (Table 1 and Fig. 1$)$.

Table 1. Determination of vitamin $\mathrm{C}$ content in fresh vegetables $(\mathrm{mg} / 100 \mathrm{~g})$.

\begin{tabular}{ll}
\hline Vegetable & Mean \pm S.D \\
\hline Coriander & $125.78 \pm 1.20$ \\
Small chilli & $96.19 \pm 0.61$ \\
Bitter guard & $56.64 \pm 0.58$ \\
Cabbage & $45.02 \pm 0.58$ \\
Giant Chilli & $36.23 \pm 0.46$ \\
Lemon & $25.5 \pm 1.76$ \\
\hline
\end{tabular}

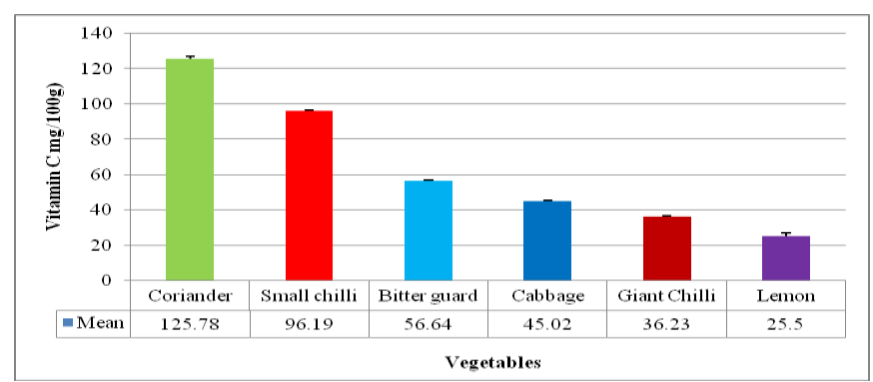

Fig. 1: Determination of vitamin $C$ content in fresh vegetables. 


\section{Coriander}

Percentage reduction in vitamin $\mathrm{C}$ content in coriander after 2, 4 and 6 days of storage at refrigerated temperature $\left(4^{\circ} \mathrm{C}\right)$ was found out to be $17.02,34.86$ and $54.86 \mathrm{mg} / 100 \mathrm{~g}$ respectively (Fig. 2). In contrast, the percentage reduction after 2, 4 and 6 days of storage at room temperature was found out to be $31.89,61.18$ and $80.86 \mathrm{mg} / 100 \mathrm{~g}$ respectively (Fig. 2).

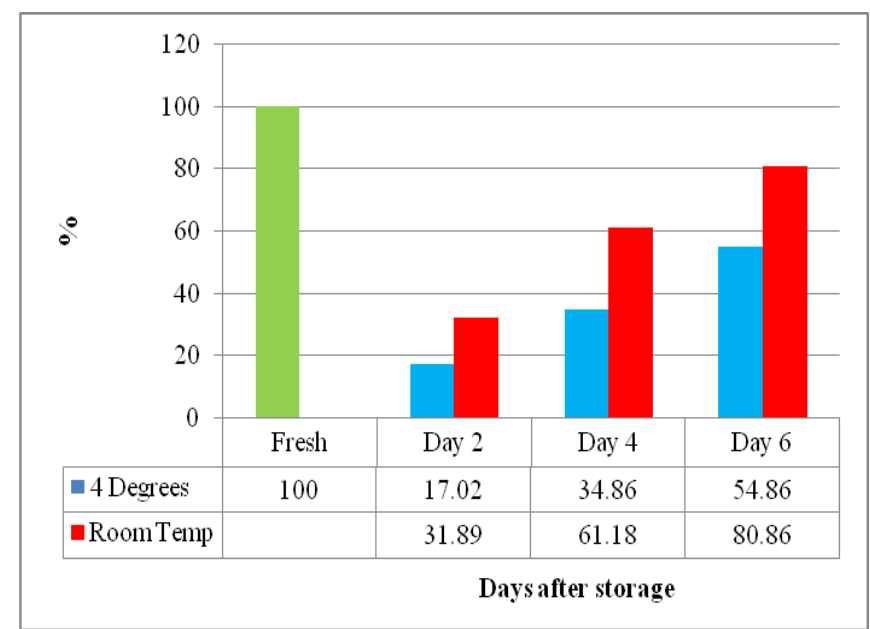

Fig. 2: Reduction of vitamin $\mathrm{C}$ content in coriander.

\section{Small chilli}

Percentage reduction in vitamin $\mathrm{C}$ content in small chilli after 2,4 and 6 days of storage at refrigerated temperature $\left(4^{\circ} \mathrm{C}\right)$ was found out to be $30.56,53.20$ and $69.97 \mathrm{mg} / 100 \mathrm{~g}$ respectively (Fig. 3). In contrast, the percentage reduction after 2, 4 and 6 days of storage at room temperature was found out to be 52.22, 75.32 and $84.66 \mathrm{mg} / 100 \mathrm{~g}$ respectively (Fig. 3).

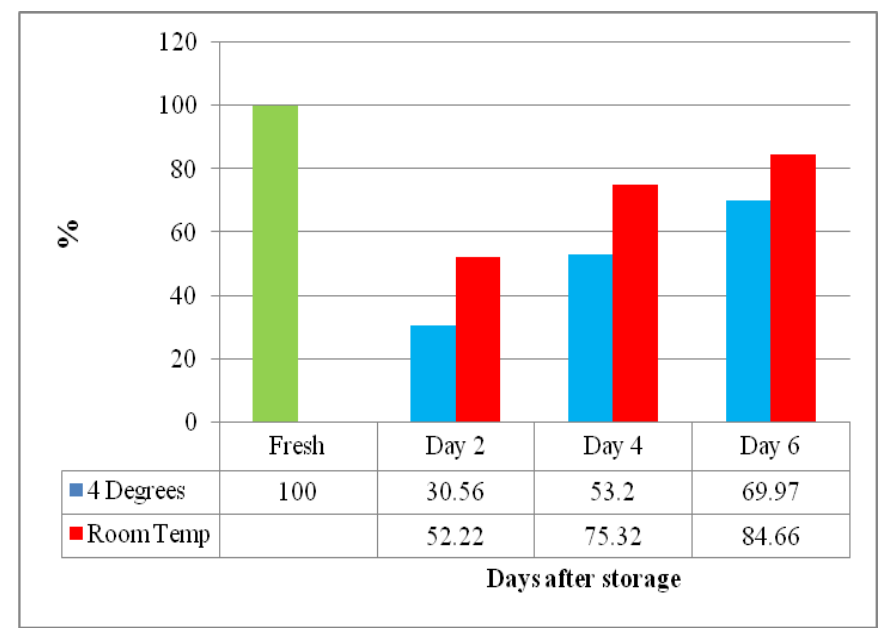

Fig. 3: Reduction of vitamin $\mathrm{C}$ content in small chilli.

\section{Bitter guard}

Percentage reduction in vitamin $\mathrm{C}$ content in bitter guard after 2,4 and 6 days of storage at refrigerated temperature $\left(4^{\circ} \mathrm{C}\right)$ was found out to be $9.36,35.77$ and $50.78 \mathrm{mg} / 100 \mathrm{~g}$ respectively (Fig. 4). In contrast, the percentage reduction after 2, 4 and 6 days of storage at room temperature was found out to be 53.98, 70.34 and $81.01 \mathrm{mg} / 100 \mathrm{~g}$ respectively (Fig. 4).

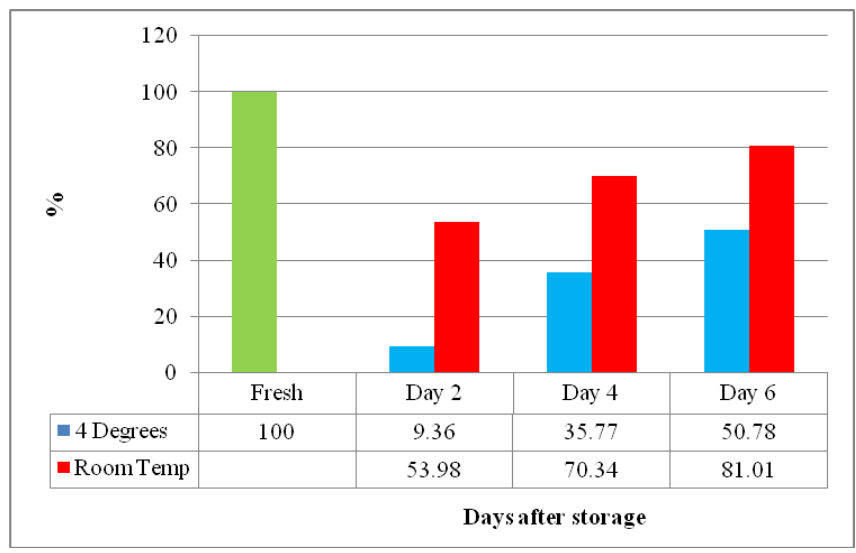

Fig. 4: Reduction of vitamin $\mathrm{C}$ content in bitter guard.

\section{Cabbage}

Percentage reduction in vitamin $\mathrm{C}$ content in cabbage after 2, 4 and 6 days of storage at refrigerated temperature $\left(4^{\circ} \mathrm{C}\right)$ was found out to be $13.57,29.79$ and $45.58 \mathrm{mg} / 100 \mathrm{~g}$ respectively (Fig. 5). In contrast, the percentage reduction after 2, 4 and 6 days of storage at room temperature was found out to be $32.88,53.62$ and $67.13 \mathrm{mg} / 100 \mathrm{~g}$ respectively (Fig. 5).

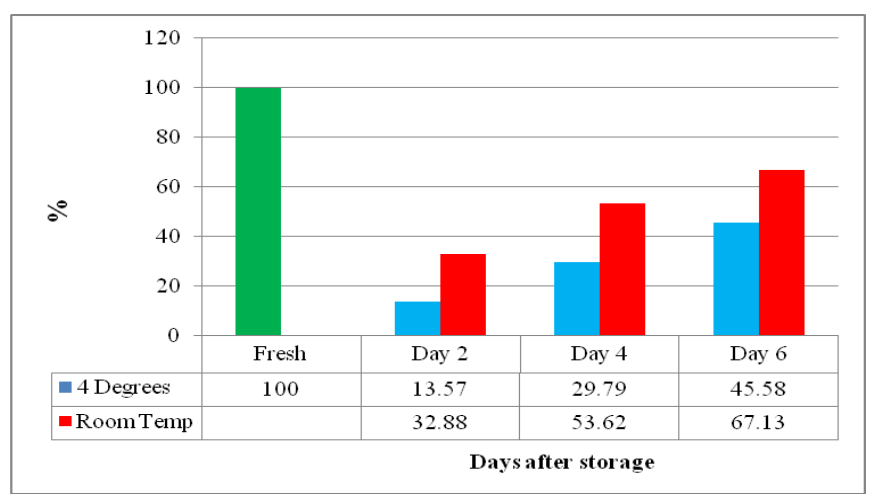

Fig. 5: Reduction of vitamin $C$ content in cabbage.

\section{Giant chilli}

Percentage reduction in vitamin $\mathrm{C}$ content in giant chilli after 2, 4 and 6 days of storage at refrigerated 
temperature $\left(4^{\circ} \mathrm{C}\right)$ was found out to be $15.53,32.43$ and $44.63 \mathrm{mg} / 100 \mathrm{~g}$ respectively (Fig. 6). In contrast, the percentage reduction after 2, 4 and 6 days of storage at room temperature was found out to be $27.87,66.65$ and $79.35 \mathrm{mg} / 100 \mathrm{~g}$ respectively (Fig. 6).

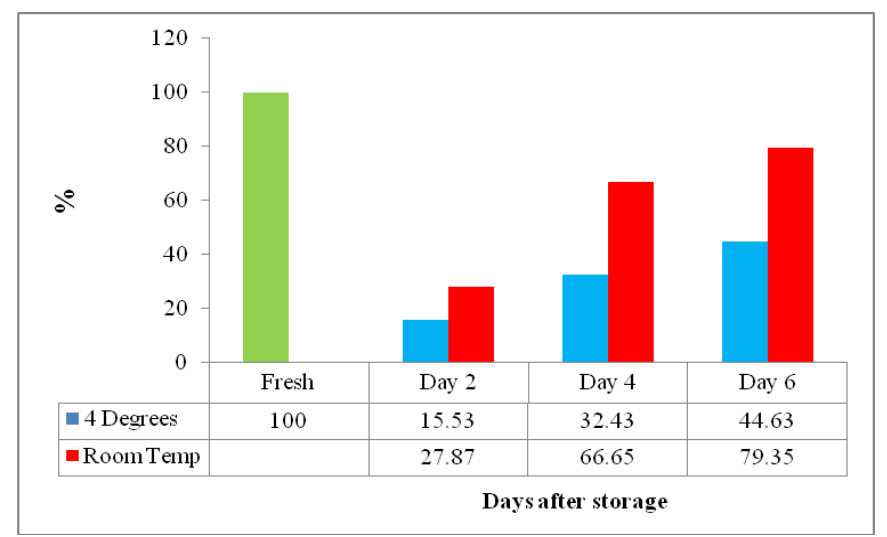

Fig. 6: Reduction of vitamin $\mathrm{C}$ content in giant chilli.

\section{Lemon}

Percentage reduction in vitamin $\mathrm{C}$ content in lemon after 2, 4 and 6 days of storage at refrigerated temperature $\left(4^{\circ} \mathrm{C}\right)$ was found out to be 5.34, 20.67 and 38.99 $\mathrm{mg} / 100 \mathrm{~g}$ respectively (Fig. 7). In contrast, the percentage reduction after 2, 4 and 6 days of storage at room temperature was found out to be 20.67, 54.67 and $75.53 \mathrm{mg} / 100 \mathrm{~g}$ respectively (Fig. 7).

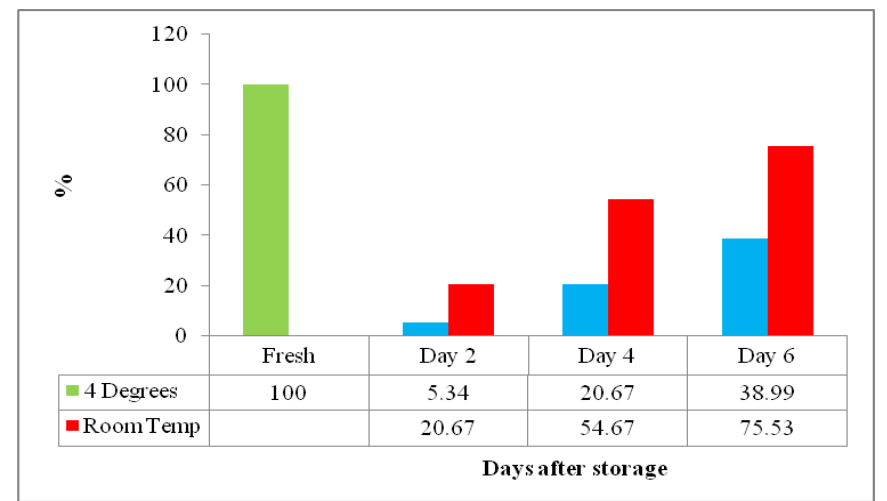

Fig. 7: Reduction of vitamin C content in lemon.

It was noticed that the vitamin $\mathrm{C}$ content reduced drastically in all the vegetables during their storage. Minimum and maximum average loss of vitamin $\mathrm{C}$ content of vegetables stored at refrigerated temperature $\left(4^{\circ} \mathrm{C}\right)$ was found out to be 15.23 and $50.80 \mathrm{mg} / 100 \mathrm{~g}$ (Table 1). In contrast, the minimum and maximum average loss of vitamin $\mathrm{C}$ content of vegetables stored at room temperature was found out to be 36.59 and 78.60 $\mathrm{mg} / 100 \mathrm{~g}$ (Table 1). These observations clearly suggest that percentage reduction was much higher in vegetables stored at room temperature as compared to those stored at refrigerated temperature $\left(4^{\circ} \mathrm{C}\right)$. Nearly $75-80 \%$ of vitamin $\mathrm{C}$ content was lost in vegetables stored at room temperature as compared to those stored at refrigerated temperature $\left(4^{\circ} \mathrm{C}\right)(50-55 \%)$.

\section{Conclusion}

Thus, it is clear from our studies that the freshest, and most probably the best quality of vegetable in terms of its nutritive value would be the immediate post-harvest 'garden fresh'. Garden fresh vegetables are seldom available in few villages only which cannot be purchased by consumers living in cities. Therefore, consumer living in cities usually purchase vegetable either from a green grocer, vegetable vendor or, more commonly now, from the supermarket. Vegetables purchased from the greengrocer and vegetable vendor are traditionally transported and stored pending sale at ambient temperature, whilst that purchased from the supermarket, 'supermarket fresh', has most probably been transported and stored at chill temperature. Only few consumers can afford to purchase vegetables from such 'supermarket fresh'. The reason may be either due to lack of such super markets in certain areas or may be the higher prices of vegetables as compared to the prices at which they are sold by greengrocer and vegetable vendor.

\section{Conflict of interest statement}

Authors declare that they have no conflict of interest.

\section{Acknowledgement}

Authors are thankful to Management and Prof. Y.Ashok, Principal of Bhavan's Vivekananda College, Secunderabad, for providing necessary facilities and constant encouragement.

\section{References}

Benzie, I. F. F., 1999. Prospective Functional Markers for Defining Optimal Nutritional Status: Vitamin C. Proc. Nutr. Soc. 58, 1-8.

Brody, T., 1994. Nutritional Biochemistry, Academic Press, San Diego, CA. pp.450-459.

Cioroi, M., 2007. Study on L-ascorbic acid contents from exotic fruits. Cercetări Agronomice în 
Moldova, Anul XXXX, Vol. 1 (129).

Davey, M.W., Montagu, M.V., Inze, D., Sanmartin, M., Kanellis, A., Smirnoff, N., Benzie, I.F.F., Strain, J. J., Favell, D., Fletcher, J., 2000. Plant L-ascorbic acid: Chemistry, function, metabolism, bioavailability and effects of processing. J. Sci. Food Agric. 80, 825-860.

Deekshika, B., Praveena Lakshmi, B., Singuluri, H., Sukumaran, M.K., 2015. Estimation of ascorbic acid content in fruits and vegetables from Hyderabad, India - A theoretical assessment of vitamin C activity Int. J. Curr. Microbiol. Appl. Sci. 4(1), 9699.

El-Ishaq, A., Obirinakem, S., 2015. Effect of temperature and storage on vitamin $\mathrm{C}$ content in fruits juice. Int. J. Chem. Biomol. Sci. 2, 17-21.

Goodman, M.P., Czelusniak, C.A., Page, S. L., Schnerder, H., Shoshani, J., Gunnell, G., Groves, C.P., 1998. Toward phylogenetic classification of primates based on DNA evidence complemented by fossil evidence. Mol. Phylogenet. Evol. 9, 585598.

Jany, M. N. H., Sarker, C., Mazumder, C. M. A. R., Shikder, M. F. H., 2008. Effect of storage conditions on quality and shelf life of selected winter vegetables, J. Bangl. Agril. Univ. 6(2), 391-400.

Lee, S. K., Kader, A. A., 2000. Pre-harvest and postharvest factors influencing vitamin $\mathrm{C}$ content of horticultural crops. Postharv. Biol. Technol. 20, 207-220.

Li, Y., Schellhorn, H.E., 2007. New development and novel therapeutic perspectives for vitamin C. J. Nutr. 137, 2171-84.

Njoku, P.C., Ayuk, A.A., Okoye, C.V., 2011. Temperature effects on vitamin $\mathrm{C}$ content in citrus fruits. Pak. J. Nutr. 10(12), 1168-1169.

Rao, B., Deshpande, V., 2006. Experimental Biochemistry. Tunbridge Wells, Kent: Anshan.

\section{How to cite this article:}

Ganesh Sandeep, B. V. S. R. K. P., Jha, P. K., Raju, K., Sukumaran, M. K., 2017. Stability of vitamin C in selected vegetables under different storage conditions. Int. J. Curr. Res. Biosci. Plant Biol. 4(8), 101-105. doi: https://doi.org/10.20546/ijcrbp.2017.408.013 